\title{
Profitability of Smallholder Sugarcane Farming in Swaziland: The Case of Komati Downstream Development Programme (KDDP) Sugar Farmers' Associations, 2005-2011
}

\author{
Mandla B. Dlamini ${ }^{1} \&$ Micah B. Masuku ${ }^{2}$ \\ ${ }^{1}$ P. O. Box C1037, Manzini Hub, Swaziland \\ ${ }^{2}$ Department of Agricultural Economics and Management, University of Swaziland, Swaziland \\ Correspondence: Micah B. Masuku, Department of Agricultural Economics and Management, University of \\ Swaziland, Swaziland. Tel: 268-7602-6557. E-mail: mbmasuku@uniswa.sz
}

Received: July 17, 2012 Accepted: August 15, 2012 Online Published: August 25, 2012

doi:10.5539/sar.v2n1p8 URL: http://dx.doi.org/10.5539/sar.v2n1p8

\begin{abstract}
Smallholder sugarcane growing is central to rural development and poverty alleviation in Swaziland. The main objective of the study was to investigate the profitability of smallholder sugarcane farmers' associations under KDDP and to explain the determinants of sugarcane profitability. The study used data from 2004/05 to 2010/11 production seasons for 15 smallholder sugarcane farmers' associations under KDDP. A structured questionnaire was used to solicit production and financial data. Secondary data were obtained from accounting records of the farmers. The associations were purposively selected because of their experience in sugarcane production. Descriptive statistics such as mean, standard deviation, minimum and maximum values were used in data analysis. The cost and returns analysis was used to assess the profitability, whilst multiple linear regression analysis was used in identifying the determinants of profitability. The associations were found to be profitable with a mean profit per hectare of E5080.00. The further results indicated that variables such as farm size, farming experience, sucrose price, labour cost per hectare and fertilizer cost per hectare significantly $(\mathrm{p}<0.01)$ influence the profitability of smallholder sugarcane farmers' associations in the study area. The adjusted $\mathrm{R}^{2}$ was 0.623 , suggesting that about $62.3 \%$ in the variation in profit per hectare is explained by the explanatory variables. It is, therefore recommended that good crop husbandry practices like timely weeding, fertilization, and irrigation should be adopted to produce a good crop which will enhance profitability. There is need for the promotion of collective action as an institutional means to improve bargaining power of farmers, especially when procuring inputs. Collective action will enable smallholder sugarcane farmers to buy in bulk and be entitled to discounts and that can enhance sustainability of profitability of the farmers.
\end{abstract}

Keywords: profitability, smallholder farmers, sugarcane, KDDP

\section{Introduction}

The sugar sector is central to the economy of Swaziland, and it accounts for $59 \%$ of the agricultural output, $35 \%$ of agricultural wage employment and $18 \%$ to the country's Gross Domestic Product (GDP) (Swaziland Sugar Association, 2011). The country is a low-cost producer of sugar hence it can sustainably produce sugar. Swaziland has in the past enjoyed preferential market access for its sugar in the United States and Europe, making sugarcane production such a viable enterprise. With the country facing high levels of poverty and unemployment, the sector could make a meaningful vehicle to fighting these problems. Smallholder sugarcane farming is now practiced by 1440 farmers particularly those in the poverty stricken areas of the Lowveld. Sugarcane production provides opportunities for employment and improved incomes, hence reduction in poverty.

\subsection{Smallholder Sugarcane Production in Swaziland}

According to Machethe et al. (2004), smallholder agriculture is important to employment, human welfare, and political stability in Sub-Saharan Africa. In addition, smallholder agriculture can moderate the rural exodus, create growth linkages and enlarge the market for industrial goods. Smallholder agriculture is also considered to be both a major cause of and potential solution to poverty and economic growth challenges (Machethe et al., 2004). 
Smallholder sugarcane growing is central to rural development and poverty alleviation in Swaziland and this is composed of farmers with 2 ha to 5 ha of under sugarcane farming per farmer. Essentially, the main objective of smallholder sugarcane growing is to reduce poverty through increased household income. It is a national policy that efficient competitive smallholder sugarcane growing be encouraged (Government of Swaziland, 2005). This can be achieved by increasing the efficiency and competitiveness of commercial smallholder sugarcane growers through improved and cost-effective production methods. Another strategy could be by monitoring the profitability and financial situation of smallholder sugarcane growers and develop contingency plans to be implemented in the event of financial failure.

\subsection{Factors Influencing Smallholder Sugarcane Profitability}

Masuku (2011) investigated the determinants of profitability for smallholder sugarcane growers in Swaziland and provided considerable insights regarding the factors affecting the performance of smallholder farmers in the sugar industry. He found that profitability of the sugarcane farmers was affected by the yield per ha, the farmer's experience, sucrose content in the sugarcane, the change in the production quota of the farmers and the distance between the farm and the mill. Similarly, Kamruzzaman and Hasanuzzaman (2007) studied the factors affecting the profitability of sugarcane production in Bangladesh. The study revealed that family labour cost, cost of urea, frequency of fertilizer applications, cost of seedcane were important factors in influencing the profitability of sugarcane production.

According to M. Dlamini (personal communication, October 25, 2011), through his vast experience in the sugarcane industry, there are numerous factors that determine sugarcane profitability. He reiterated that management determinants such as labour should be closely monitored in as far as planting, weeding, irrigation, fertilizer application and harvesting in order to improve profitability. Under-utilizing or over-utilizing labour affects the overall profitability of sugarcane. On the same breath agronomic factors such as varieties planted, soil fertility, system of irrigation and planting time determine the level of profits to be attained in a sugarcane enterprise.

Harb and Columba (2010) identified fertilizer, weed control, soil sampling, replanting with treated seedcane, and the use of herbicides as critical to producing above-average sugarcane yields. Harb and Columba (2010) also emphasized that the harvesting operation affects farm profitability. Rates of return on debt above the interest rate will increase profits, while rates of return below the interest rate will reduce profits. The interest rate charged on a loan effectively measures the price the farmer has to pay for the loan.

The sugar industry is currently faced with an array of challenges, and is in a period of uncertainty, as the situation on its major export market changed dramatically. The European Union (EU) has reformed its internal sugar market with a resultant drop in the EU price and with no guarantees on the preferential market as it has recently been eroded. This has resulted in sugar revenues reduced substantially. In total the EU reforms has resulted in sugar price decrease by $36 \%$ and this has affected the performance of the sugar industry. This further impacts negatively the viability of the sugar sector, whose strength was not only on the low cost of production but also the sales to preferential markets (Swaziland Sugar Association, 2011).This study, therefore, assessed the factors affecting the profitability of smallholder sugarcane production by farmers' associations. The findings of the study will provide both smallholder sugarcane farmers and the Swaziland government with factors that needs to be promoted in to improve and sustain the profitability of sugarcane farming.

\section{Methodology}

\subsection{Research Design}

The study employed a descriptive research design. The main objective of the study was to identify the factors affecting profitability of smallholder sugarcane growers' associations under KDDP. These associations are located in the Lowveld of Swaziland, with the farms nestled along the Komati River from Madlangempisi, down to Mananga Border Gate in the North-Eastern part of Swaziland.

\subsection{Sampling Procedure and Data Collection}

The KDDP area was purposively chosen for this study because the farmers' associations in this area operate in homogenous agro-climatic conditions and sugarcane is the major crop enterprise in the area and moreover because of their experience in sugarcane production. The study used 2004/2005 to 2010/2011 production seasons data from 15 smallholder sugarcane farmers' associations under KDDP.

Data from the smallholder sugarcane farmers' associations were obtained from farmers' production records. The records were obtained from Swaziland Water and Agricultural Development Enterprise (SWADE). Additional data were sought from farmers by means of a questionnaire. 


\subsection{Data Analysis}

Descriptive and inferential statistics were used and the Statistical Package for Social Sciences (SPSS version 17) was used to analyze the data. The descriptive statistics included means, standard deviation, minimum and maximum values, while the multiple linear regression function was employed to analyze the determinants of sugarcane profitability. It is a simple function to employ especially when both the dependent and the explanatory variables are linear. Cost and returns analysis was used to assess the level of profitability of smallholder sugarcane growers. Profit per hectare from sugarcane production was calculated by deducting the total cost of sugarcane production from the gross income.

\subsection{Econometric Model}

An econometric model for the profitability of sugarcane is of the linear type as given by;

$$
\mathrm{Y}=\mathrm{f}\left(\mathrm{X}_{1} \mathrm{X}_{2} \mathrm{X}_{\left.3, \cdots, \mathrm{X}_{\mathrm{n}}\right)}\right. \text {. }
$$

Therefore, for this study a multiple regression model was used as it fits into the type of variables that influence profitability. Hence, the function is specified as:

$$
Y=\beta_{0}+\beta_{1} X_{1}+\beta_{2} X_{2}+\beta_{3} X_{3}+\beta_{4} X_{4}+\beta_{5} X_{5}+\beta_{6} X_{6}+\beta_{7} X_{7}+\beta_{8} X_{8}+\beta_{9} X_{9}+\varepsilon
$$

Where;

$\mathrm{Y}=$ Profitability (profit/ha)

$\beta_{0}=$ Constant

$\beta_{1} \ldots \beta_{9}=$ Parameters to be estimated

$\mathrm{X}_{1}=$ Farm size (ha)

$\mathrm{X}_{2}=$ Farming experience (yrs)

$\mathrm{X}_{3}=$ Number of ratoons (yrs)

$\mathrm{X}_{4}=$ Field visits frequency

$\mathrm{X}_{5}=$ EU reforms (dummy)

$\mathrm{X}_{6}=$ Labour costs per ha $(\mathrm{E})$

$\mathrm{X}_{7}=$ Fertilizer costs per ha $(\mathrm{E})$

$\mathrm{X}_{8}=$ Sucrose price $(\mathrm{E} /$ tonne $)$

$\mathrm{X}_{9}=$ Farm manager's age (yrs)

$\varepsilon=$ Random error term.

\subsection{Explanation of Variables and A Priori Expectations}

Profitability (Y): This is the dependent variable and measured by profit per ha (Emalangeni/ha). It is assumed that it is determined by all the explanatory variables included in the model.

Farm size $\left(\mathrm{X}_{1}\right)$ : The size of the farm has an effect on the profitability of the enterprise because farmers' associations with a small farm may produce a good yield only to find that his returns are lower, owing to costs incurred as a result of economies of size.

Farming experience $\left(\mathrm{X}_{2}\right)$ : The number of years a farmers' association has been involved in sugarcane farming is a proxy of the management capability of the association. It is expected to have an influence in the farmers' associations' management skills as well as improved interaction with the mill where they deliver their sugarcane. Through the interaction, the farmers may develop some confidence in sugarcane farming by applying the required management expertise to produce a good crop. Thus, farmers who had been involved in the sugarcane farming for several years are expected to perform better than relatively new farmers. Therefore, a positive relationship is expected between farming experience and profit per hectare.

Number of ratoons $\left(\mathrm{X}_{3}\right)$ : Sugarcane grows from ratoons after the first harvest and the continuous growth of the sugarcane year after year does not require that the fields be replanted. The age of the sugarcane results in subsequent crop not growing to their full potential and as such yield is compromised. A negative relationship is expected between the number of ratoons and profitability.

Field visits frequency $\left(\mathrm{X}_{4}\right)$ : Smallholder sugarcane growers' associations receive extension services in order to manage the crop well. The number of visits that they are afforded by the extension officers is hypothesized to result in a good crop hence profitability of their enterprises. A positive relationship is expected between field 
visits and profit.

EU reforms $\left(\mathrm{X}_{5}\right)$ : The EU sugar market has removed the preferential status of Swaziland and the sugar price has since been reduced by $36 \%$ since 2009 . The removal of the preferential treatment accorded to Swaziland and other sugar- producing countries for sugar exports to the European Union is expected to negatively affect the profit per hectare that the farmers' associations get.

Labour cost per hectare $\left(\mathrm{X}_{6}\right)$ : Labour is fundamental in any production enterprise and sugarcane farming is no exception. Costs increases expenditure and if poorly monitored they can reduce the viability of a business. A negative relationship is expected between labour costs per hectare and profitability.

Fertilizer cost per hectare $\left(\mathrm{X}_{7}\right)$ : Fertilizers are needed for a good sugarcane crop and they increase the cost component in production. A negative relationship is expected between fertilizer cost per hectare and profitability.

Sucrose price $\left(\mathrm{X}_{8}\right)$ : The price at which the sucrose is bought is very important towards determining what the farmers' associations eventually receive for their produce. A positive relationship is expected between sucrose price and the profit per hectare.

Farm manager's age $\left(\mathrm{X}_{9}\right)$ : This represents the knowledge that the manager has supposedly acquired in the industry. Experience comes with age and therefore, a positive relationship is expected between age and profitability.

\section{Results and Discussion}

\subsection{The Descriptive Statistics of KDDP Smallholder Farmers' Associations}

Table 1 presents the descriptive statistics for smallholder sugarcane farmers' associations in the study area. The results indicate that the farmers' associations are dominated by females in terms of membership with a mean of 69 female members compared to a mean of 46 for male members. The results further reveal that the farmers' association had a mean of 6.05 years of farming experience in sugarcane production. The farmers' associations' farms are on average $28.63 \mathrm{~km}$ from the sugar mill, with the nearest being $13 \mathrm{~km}$ and the furthest $44 \mathrm{~km}$ away. The average farm size under cane cultivation is 164.37 ha with the minimum and maximum farm sizes being 42.80 ha and 336.30 ha respectively. The farmers' associations spent on average E339237.81 and E612497.39 on labour and fertilizer respectively. This is an indication that sugarcane production is labour intensive and the inputs are costly.

Table 1. Descriptive statistics of smallholder sugarcane farmers' associations under KDDP

\begin{tabular}{lllll}
\hline Variable & Sample Mean & Standard Deviation & Minimum Value & Maximum Value \\
\hline Farming experience (yrs) & 6.048 & 2.259 & 1 & 11 \\
Members of Association & 115.048 & 87.978 & 29 & 379 \\
Number of males & 46.152 & 58.147 & 10 & 250 \\
Number of females & 69.467 & 44.358 & 18 & 179 \\
Farm size (ha) & 164.37 & 75.09 & 42.8 & 336.3 \\
Labour cost per ha & $339,237.81$ & $2.27 \mathrm{E}+05$ & $9.08 \mathrm{E}+04$ & $1,451,657.30$ \\
Fertilizer cost per ha & 612497.388 & $5.21 \mathrm{E}+05$ & 71603.15 & 3158242 \\
Number of Ratoons (yrs) & 4.324 & 2.137 & 1 & 9 \\
Distance to the mill (km) & 28.633 & 8.355 & 13 & 44 \\
Sucrose yield (tonnes) & 2423.687 & 1255.973 & 551.2 & 8049.85 \\
Field visits freq (times/month) & 1.505 & 0.521 & 1 & 3 \\
Farm manager's age (yrs) & 38.2 & 9.414 & 26 & 63 \\
\hline
\end{tabular}

The results further indicate that the mean sucrose yield produced is 2423.687 tonnes. The minimum sucrose yield is 551.2 tonnes and the maximum is 8049.85 tonnes and this can be attributed to both the farm size and the management capabilities of the producers. The farm managers' ages range from 26 years to 63 years and they possess either a certificate or a diploma as their education. 


\subsection{The Profitability of KDDP Smallholder Sugarcane Farmers' Associations}

The profitability analysis of the growers' associations under KDDP is presented in Table 2. The mean total revenue from the sale of the sugarcane crop was estimated at E10011668.83 and the minimum was E4225400.0. The total costs in general do not outweigh the revenue and that signals a positive return to smallholder sugarcane production in the study area.

Table 2. Profitability of KDDP smallholder sugarcane farmers' associations

\begin{tabular}{lllll}
\hline Variables & Mean $(\mathrm{E})$ & Minimum & Maximum & SD \\
\hline Total Revenue & $4,225,400.00$ & $926,339.70$ & $10,011,668.83$ & $2,279,360$ \\
Total Cost & $2,680,897.00$ & $689,453.67$ & $3,462,987.00$ & $1,869,579$ \\
Profit & $501,909.00$ & $(256,466.00)$ & $6,466,650.00$ & $1,152,540$ \\
Profit/ha & $5,080.00$ & $(22.00)$ & $31,820.00$ & $5,688.39$ \\
\hline
\end{tabular}

Note: Figures in parenthesis represent negative values

Profit estimates were positive although some associations made losses which mainly could be as a result of high interest rates for operational loans which are payable within a single production season. The profit per hectare shows a positive mean, which indicates that sugarcane farming is a viable and profitable enterprise in the study area. With a number of associations finishing repaying their capital loans in the near future, the profitability of these enterprises will improve.

\subsection{Determinants of Profitability of KDDP Smallholder Sugarcane Farmers' Associations}

The estimates of the parameters of the multiple regression function model were obtained through the use of the Statistical Package for Social Sciences (SPSS ver. 17). The results of the regression analysis are presented in Table 3.The following variables were significant in determining the profitability of smallholder sugarcane farmers' associations Farm size, farming experience, sucrose price, fertilizer costs per hectare, and labour costs per hectare. The results indicate that land under sugarcane (farm size) had a negative but significant relationship $(\mathrm{p}<0.05)$ with the profit per hectare. This showed that an increase by a hectare of the sugarcane grown would result in a drop in the profit per hectare realized by E19.96. This result was not expected. This could be a result of poor management. This result was similar to that of Olujenyo (2010) who concluded that farm size was negatively related to the profitability of maize production. Dlamini et al. (2010) also concluded that as the size of the sugarcane farm increases, technical efficiency of smallholder sugarcane farmers' associations decline and that leads to a poor crop, which negatively affects the profit. This result can be attributed to the fact that the sugarcane farmers' associations under KDDP are smallholders and as such managing larger farms could pose managerial challenges towards producing a good crop since their managers may be accustomed to managing smaller farms. Procuring adequate inputs for a large farm may be a challenge and as such smallholder sugarcane associations may be tempted to apply fewer amounts of inputs per hectare.

The coefficient for farming experience was 842.797 and significant at $(\mathrm{p}<0.05)$ and had positive relationship with profit per hectare. This means that an increase in farming experience by 1 year will result in an increase of E842.797 profit per hectare. Labour cost per hectare had a coefficient of -0.998 and it was significant $(p<0.05)$. The negative relationship between labour cost per hectare and profit per hectare means that E1 increase in the cost of labour will reduce profit per hectare by E0.998. Fertilizer cost per hectare exhibited a negative relationship with profit per hectare and was significant $(\mathrm{p}<0.01)$, implying that a E1 increase in the fertilizer cost used on sugarcane will result in a decrease in the profit per hectare of E2.53.

Sucrose price had a coefficient of 5.228 and statistically significant $(\mathrm{p}<0.01)$. This means that a E1 per tonne increase in the sucrose price translates to about E5.23 increase in the profit per hectare. 
Table 3. Determinants of profitability for KDDP smallholder sugarcane farmers' associations

\begin{tabular}{lll}
\hline Variable & Coefficients & t-statistics \\
\hline Constant & -2262.25 & -1.088 \\
Farm size (ha) & $-19.96^{*}$ & -2.779 \\
Number of ratoons (yrs) & 0.039 & 0.247 \\
Farm Manager's age (yrs) & 0.061 & 0.735 \\
Education level (dummy) & -0.022 & -2.13 \\
Sucrose price (E/tonne) & $5.228^{* *}$ & 2.584 \\
Labour cost /ha (E/ha) & $-0.998^{*}$ & -2.496 \\
Fertilizer cost/ha (E/ha) & $-2.533^{*}$ & -2.791 \\
Farming experience (yrs) & $842.797^{* *}$ & 3.705 \\
EU sugar reforms (dummy) & -931.291 & -0.465
\end{tabular}

$\mathrm{R}=0.696 ; \mathrm{R} 2=0.65 \overline{5 ; \text { Adjusted R2 }=0.523 ; \text { F-statistic }=29.920 ; \mathrm{df}=104 ; \text { Durbin-Watson }}=1.928$.

Notes: $* *=$ significant at 0.01 level, $*=$ significant at 0.05 level.

The drop in the sugar price due to the EU sugar reform was expected to significantly affect the profit per hectare that smallholder sugarcane farmers' associations realized. However, the variable EU reforms, was insignificant. This was rather unexpected bearing in mind that the sugar price had dropped by a staggering $36 \%$. This result can be attributed to the fact that the EU and the government of Swaziland have put in place mitigation measures to ameliorate the effects of the price cuts. The EU is currently giving grants of $70 \%$ towards development costs to smallholder sugarcane farmers' associations to cushion the effects of the high debts they could incur. This, therefore, has lowered the costs and hence the enterprises are still profitable. Rebates were also given to all farmers associations in 2009 for all development costs (i.e. land preparation and irrigation infrastructure costs) they had incurred. The provision of the grants by the European Union is part of the accompanying measures for Sugar Protocol countries (AMSP) that the EU adopted to support the adaptation process in countries affected by the EU sugar reforms.

The frequency of visit by extension officers was -0.022 and statistically insignificant. Visit by extension officers was expected to be positively related to profitability. Though insignificant, it was however, insignificant. The variable, number of ratoons was not statistically significant though it posted a positive sign. This was contrary to the a priori expectations of the study. The adjusted $\mathrm{R}^{2}$ of 0.623 indicates that about $62.3 \%$ of the variation smallholder sugarcane farmers' associations' profit per hectare is explained by all the explanatory variables discussed above. This represents a fair goodness of fit to ensure that the chosen explanatory variables were able to influence the dependent variable. The F-statistic of 29.92 explains the significant relationship between profit per hectare and the explanatory variables. The Durbin-Watson value of 1.928 indicates that there was less threat of serial correlation between the explanatory variables.

\section{Conclusions}

The study investigated the profitability of smallholder sugarcane farmers' associations under KDDP in Swaziland. The results of the study provide considerable insights into the determinants of profitability in the study area, the smallholder sugarcane farmers' associations were found to be making profit from the sugarcane enterprise. The study concludes that farm size, labour costs, fertilizer costs, farming experience, sucrose price all have a significant effect on profitability.

\section{Recommendations}

The results from the study revealed that labour costs and fertilizer costs are among the key determinants of profitability. It is, therefore, vital that the smallholder farmers use the recommended amount of labour from the standards detailed in the sugar industry. This would help cut on unnecessary expenditure. Timely scheduling of field operations is very important to ensure that labour is neither underutilised nor over utilised, both of which affect the profitability. Proper crop husbandry skills are needed so that the farmers would be in a position to apply all the inputs in optimal amounts to save costs. Fertilizer costs are forever fluctuating and it can be 
recommended that cooperatives be formed in the study area so that fertilizer can be bought in bulk and discounts received. This will ensure that the expenditure would be reduced resulting in higher and sustainable profits.

\section{References}

Bagamba, F., Ssenyonga, J. W., Tushemereirwe, W. K., \& Gold, C. S. (1999). Performance and profitability ofthe banana sub-sector in Ugandafarming systems.Bananas and Food Security. Proceedings of an international symposium held in Douala, Cameroon, 10-14 November: 729- 740.

Dlamini, S., Rugambisa, J. I., Masuku, M. B., \& Belete, A. (2010).Technical Efficiency of the Small-scale sugarcane farmers in Swaziland.A case of Vuvulane and Bigbend farmers. African Journal of Agricultural Research, 5(9), 935-940.

Government of Swaziland. (2005). Comprehensive Agriculture Sector Policy. Mbabane, Swaziland.

Harb, J. C., \& Columba, C. H. (2010). Financial and Economic feasibility of sugarcane production in northern Lapaz. Latin American and Carribbean Environmental Economics Program.

Kamruzzaman, M., \& Hasanuzzaman, M. (2007). Factors affecting profitability of sugarcane production as monoculture and as intercrop in selected areas of Bangladesh. Bangladesh Journal of Agricultural Research, 32(3), 433-444.

Machethe, C. L., Mollel, N. M., Ayisi, K., Mashatola, M. B., Anim, F. D. K., \& Vanasche, F. (2004). Smallholder Irrigation and Agricultural Developmentin the Olifants River Basin of Limpopo Province:Management Transfer, Productivity, Profitability andFood Security Issues.Report to the Water Research Commission on the project entitled "Sustainable Local Management of Smallholder Irrigation"University ofthe North,School of Agriculture and Environmental Sciences.

Masuku, M. B. (2011). Determinants of Sugarcane Profitability: The Case of Smallholder Growers in Swaziland. Asian Journal of Agricultural Sciences, 3(3), 210-214.

Olujenyo, F. O. (2010). The Determinants of Agricultural Production and Profitability in Akoko Land, Ondo-State, Nigeria. Journal of Social Sciences, 4(13), 125-131.

Swaziland Sugar Association. (2011). Swaziland Sugar Association Annual Report Mbabane, Swaziland. 